UDC 81'42:316.774-028.22:004.738.5

DOI https://doi.org/10.32999/ksu2663-2691/2020-83-19

\title{
DEMOTIVATORS AS A SPECIAL TYPE OF THE INTERNET DISCOURSE COMMUNICATION
}

\author{
Zabolotska Olha Oleksandrivna, \\ Doctor of Pedagogical Sciences, Full Professor, \\ Head of the Department of English Language \\ and Methods of Its Teaching \\ Kherson State University \\ eng.kafedra214@ukr.net \\ orcid.org/0000-0002-8899-8244
}

\author{
Zabolotska Oleksandra Volodymyrivna, \\ Candidate of Philological Science, \\ Associate Professor of the Department \\ of English Language and Methods of Its Teaching \\ Kherson State University \\ eng.kafedra214@ukr.net \\ orcid.org/0000-0003-2299-052X
}

In the situation of computerization of modern society, the influence of the media on the way of life, the worldview and the consciousness of most people is evident.

An attempt to overcome the language barrier of representatives of various linguistic cultures is playing a dominant role of nonverbal information in today's global communication and the emergence of new visual and verbal forms of the Internet communication.

The purpose is to distinguish functional and pragmatic potential of demotivators in the Internet discourse.

Methods. In the course of the study, the following methods were used: a descriptive method, the method of semantic analysis, of stylistic analysis, of interpretive and textual analysis.

Demotivational posters are a special way of transmitting information, as prepositions are important for the fullest possible understanding of its meaning: the demotivator can contain such semantic components that do not find direct expression, and the reader decodes these meanings on the basis of their own experience, knowledge of typical situations, historical and cultural background and knowledge. The main function of demotivational posters is considered to be a cognitive one, as the information presented in demotivators can form the thinking of youth audience, its evaluative and normative system. Demotivators also realize volutative, axiological, aesthetic, emotional and expressive functions and the function of forming reality.

Results. The analysis of demo poster showed that the type of demotivators can determine their pragmatic potential: original, philosophical, social and advertising demotivators promote the main values and realize the volitional intention of the speaker, i.e. suggestive impact on the recipient that helps to create a spiritual guidance and a new type of thinking among young people; humorous and esoteric demotivators depict famous facts from youth's life in an ironical and sarcastic manner, disclose social reality, have entertaining character, carrying out both emotional, expressive functions and a function of forming virtual reality.

Conclusions. Demotivational poster is a special way of transmitting information in the Internet discourse, which defines its moral and value orientations, the attitude towards the surrounding world.

Key words: iconic and verbal component, visual communication, functional and pragmatic potential.

\section{ДЕМОТИВАТОР ЯК ОСОБЛИВИЙ ТИП КОМУНІКАЦІї ІНТЕРНЕТ-ДИСКУРСУ}

\author{
Заболотська Ольга Олександрівна \\ доктор педагогічних наук, професор, \\ завідувач кафедри англійської мови та методики ї̈ \\ викладання \\ Херсонського державного університету \\ eng.kafedra214@ukr.net \\ orcid.org/0000-0002-8899-8244
}

\author{
Заболотська Олександра Володимирівна \\ кандидат філологічних наук, дочент \\ кафедри англійської мови та методики ї̈ викладання \\ Херсонського державного університету \\ eng.kafedra214@ukr.net \\ orcid.org/0000-0003-2299-052X
}

\footnotetext{
Сучасний світ можна назвати цивілізацією гіпертексту, сучасну людину - віртуальною, мережевою людиною, а сучасне суспільство - інформаційним. Стає очевидним, що вербальна комунікація припиняє існувати ізольовано, вона має тенденцію до залучення інших знакових систем, серед яких провідне місце посідає візуальна комунікація, яка унаочнює інформацію, що передається.
} 
Актуальність статті зумовлена загальною спрямованістю сучасних філологічних студій на вивчення системи комунікації 3 урахуванням ефективності мовних засобів та інтегрованості різних семіотичних ресурсів у сучасному комунікативному процесі, де простежується взаємодія вербальної складової частини повідомлення і його паравербальних (нелінгвістичних) компонентів.

Мета статті - визначити функційно-прагматичні особливості англомовних демотиваційних постерів мережі Інтернет.

Методи. У процесі дослідження було використано такі методи: описовий метод (для дескрипції характерних рис інтернетдискурсу та візуально-вербальної природи демотиваційного постеру), метод семантичного аналізу (для виявлення семантики лексичних одиниць у контексті), метод стилістичного аналізу (для визначення стилістичних засобів, що увиразнюють демотиваційні постери інтернет-дискурсу), метод інтерпретаційно-текстового аналізу (для визначення специфіки використання демотиваторів у процесі інтернет-комунікації).

Інтернет, будучи високотехнологічним і водночас високо динамічним комунікативним простором, перебуває в постійному русі, постійній еволюції. Відповідно, з'являються абсолютно нові форми інтернет-комунікації, а старі видозмінюється тим чи іншим чином.

Демотиватор (демотиваційний постер) як предмет філологічних досліджень є актуальним, оскільки нині зросла зацікавленість у проблемі полікодових або креолізованих текстів як особливих форм комунікації (банери, реклама, кліпи, демотиватори). Сучасну людину весь час оточують різні знакові системи, а невербальні засоби дедалі більше беруть участь у передачі та збереженні інформації.

Результати. Аналіз мовного матеріалу показав, що значна кількість демотиваційних постерів має синсематичний тип відношень між вербальною та візуальною його частинами. Іконічний компонент не просто доповнює розуміння вербальної складової частини повідомлення демотиватора, а й впливає на його інтерпретацію й унаочнює основну думку, заохочуючи реципієнта до певних роздумів.

Глобалізаційні процеси, які знаходять відображення в демотиваційних постерах через повтор структурно-композиційної будови тексту і стереотипне вживання мовних засобів впливу, забезпечують залучення індивідуального реципієнта до світового суспільства. Це зумовлює постійний потік стандартизованих цінностей із метою формування пересічного погляду на довколишній світ та уніфікованої картини світу.

Висновки. Демотиватор постає візуальною рефлексією реального світу, реакцією на впроваджуване позитивне мислення. Комбінація режимів сприйняття образів призводить до появи нових форм цього процесу, нового типу мислення - від вербального до візуального, образного, спрямованого на викриття традиційних цінностей та авторитетів.

Ключові слова: іконічний і вербальний компонент, візуальна комунікація, функціонально-прагматичний потенціал.

\section{Introduction}

In the life of a modern person, the role of the Internet and information technologies is constantly growing. Virtual communication touches practically all areas of human life and at present different genres of all functional styles are presented in the Internet (official sites of organizations, electronic versions of scientific, social-political and entertainment magazines, TV and radio programs, chats, blogs, forums, etc.), which extends the boundaries of international communication and becomes an example of globalization.

The English linguist D. Cristal in his monograph "Language Revolution" called the emergence of the Internet as one of the factors that led to revolutionary transformations in the language (Cristal, 2004: 64).

The occurrence of the Internet in the second half of the twentieth century as an entirely new channel for the transmission of information and as a means of mass communication caused the existence of special, inherent only to this environment, network communities, virtual worlds, culture in the network, network language.

The phenomenon of the Internet has generated not only a new communicative environment, but also became the object of numerous scientific studies, including linguistic ones. Due to the rapid development of computer technologies, in the system of humanitarian knowledge it is important to determine and examine the Internet discourse, separate a new direction of linguistic research - Internet linguistics (Halichkina, 2001: 79).

The aim is to distinguish functional and pragmatic potential of demotivators in the Internet discourse.

The aim implies solving the following tasks:

- to give characteristic of the Internet discourse as a new type of communication;

- to analyse demotivators as special forms of the Internet communication;

- to single out functional and pragmatic potential of demotivational posters in the Internet discourse.

In the course of the study, the following methods were used: a descriptive method (to describe the characteristics of the Internet-discourse and the visual and verbal nature of a demotivational poster), the method of semantic analysis (to identify the semantics of lexical units in the context), the method of stylistic analysis (for the definition of stylistic means that depict demotivational posters of the Internet discourse), the method of interpretive and textual analysis (to determine the specificity of the use of demotivators in the process of communication).

\section{The Internet discourse as a new type of communication}

In foreign linguistics, the study of the features of virtual communication began in the 80's of the twentieth century and is associated with Suzanne Barnes, Naimi Baron (нема у списку літератури), S. Herring (Herring, 2014). In philological studies of the beginning of the $21^{\text {st }}$ century the corresponding theoretical foundations and the empirical material for the investigation of virtual communication that is created in the Internet are presented. Great attention is paid to the study of the Internet discourse from the position of cognitive-translation, comparative and cognitive pragmatic approaches (V. Zgurskaya, L. Slavova, L. Kompantseva) (нема в списку літератури).

But, there is no terminology of the given type of discourse through a differentiated object of the research and the area of using. I. Shevchenko and O. Morozova, examine discourse as speech in the context of social and intellectual activity and define discourse as an integral phenomenon, as a thought-communicative activity that takes place in a broad 
socio-cultural context, is a combination of process and result, and is characterized by continuity and dialogism (Shevchenko, 2004: 26-28).

E. Sheigal gives the following definition: discourse is a system of communication, a field of communicative practices, studied in real and potential (virtual) aspects, where the real refers to the current speech activity and its results are texts, the potential dimension is a set of characters serving the individual communication (Sheigal, 2000: 42).

Thus, there is no universal term and definition of the Internet discourse. The most common are the terms "computer-mediated communication", "computer discourse", "electronic discourse", "virtual discourse", "Internet discourse" and "network discourse" (Karasik, 2000).

O. Lutovinova refers the term "computer discourse" to the text immersed in the situation of communication using electronic means of communication, more precisely, with the help of a computer. It should be noted that the terms "computer discourse" and "electronic discourse" are synonyms, as the computer is a carrier of certain technical characteristics (Lutovinova, 2009: 9).

"Internet discourse" is denoted as communication in the global network and is a kind of network discourse, which in addition to communication in the Internet includes communication in other, in particular, local networks. Thus, these types of discourse are in hyper-hyponymic relations, where hyperonomes stand for the computer (electronic) discourse, and the communicative surrounding is determined by the channel of communication (Lutovinova, 2009: 9).

Among the problems associated with the Internet discourse, the question of its structure and characteristics that distinguish it from all other types of discourse requires the attentive attitude of researchers, as the Internet discourse is extremely heterogeneous.

For virtual communication, there is also a lack of visible social, gender and age gradation (which can not be avoided in the most types of discourse). Although this type of discourse is limited by technical capabilities (the presence of a computer communicator, access to the Internet) and a human factor (finding interlocutors currently in the network and their presence at a certain resource at the moment), being artificially created by the communicative environment, the Internet discourse does not have time and space limits, it allows users to interact with each other, not depending on their geographical location and time area.

In modern linguistics the Internet discourse is interpreted differently as:

- cognitive-communicative space of the global network, in which the means of the electronic data transmission channel and the hypertextual mechanism of their structuring and routing with the help of verbal means carry out a communicative interaction occurs which is characterized by the replacement of the real image by the fictitious (Shevchenko, 2005);

- the text that exists in the Internet system, in which the persuasive communication implicitly reflects the subjectivepersonal author's viewpoint, created taking into account psychological, linguistic and technological factors (Batsevich, 2004: 7);

- a complex text system, due to extra-linguistic socio-cultural factors and the specific situation of entering speech communication with the help of a computer and other electronic devices as users of each other in the Internet, and users with a discursive Internet space (Sheigal, 2000: 3).

The Internet discourse as a kind of communication has its features that distinguish it from all other types of discourse. O. Halichkina includes the following constitutive features:

1) electronic signal as a communication channel;

2) virtuality;

3) distantness, that is, remoteness in space and time;

4) mediation by technical means;

5) high degree of permeability, as any person can become a listener, copartner or participant of the Internet discourse;

6) the presence of hypertext;

7) creolosity, that is, the presence of letters, figurative-visual and figurative-authetic components in the texts (pictures, audio and video fragments);

8) mainly the status equality of the participants;

9) the transfer of emotions, mime, feelings with the help of "emoticons";

10) a combination of different types of discourse;

11) specific ethics (Halichkina, 2001: 50-57).

According to T. Vinogradova, the Internet discourse one must take into account the features of communication through the Internet and the reasons for access to the Internet as a means of communication (Vinogradova, 2004).

These peculiarities are represented by the following components:

1. Anonymity. Despite the fact that sometimes it is possible to get some information about the personal nature and even the photo of the interlocutor, they are not enough for a real and adequate person's perception. Due to such anonymity and impunity in the network, another feature is associated with a decrease of psychological and social risk in the process of communication - affective cleftness, abnormal behavior and some irresponsibility of communication participants. A person in the network can manifest and manifests freedom of expression and deeds (up to the image, obscene expressions, sexual harassment), as the risk of exposing and personal negative evaluation by other persons is minimal.

2. The peculiarity of the process of interpersonal perception in the absence of non-verbal information. As a rule, mechanisms for stereotyping and identification have a great influence on the characteristic of the interlocutor as an expectation of the desired qualities in the partner. 
3. Voluntary and desirable contacts. The user voluntarily contacts or avoid them, and can break them at any time.

4. Difficulties in the emotional component of communication, at the same time, a consistent desire for emotional content of the text, which is expressed in the creation of special icons to denote emotions or in the description of emotions with words (in brackets after the main text of the message).

5. The desire for not typical, abnormal behavior. Often, users present themselves from the other side, different from the real social norm (Vinogradova, 2004: 64).

As communication in the Internet discourse level social, gender, age and other features, communicants are equal.

According to the scientists' viewpoint, chronotop is ambivalent in its nature - communicants exist simultaneously in several local-time positions: virtual, imagenary and real.

Speaking about the genre organization, the scientist emphasizes that the Internet discourse is becoming a genreproducing field, which does not only borrow the existing ones, but also promotes the appearing of new genres, but the analysis of genres denotes the study of the world picture. The linguistic embodiment of the Internet discourse is defined as the integration of oral and written speech in it (Vinogradova, 2004) and singling out a new form of language interaction - oral and written discourse.

The genre variation of the Internet discourse in its current state is multifaceted and quite controversial. Genre system of Internet communication differs by its complexity and multidimensionality. Thus, in modern linguistic studios there are basic studies devoted to separate genres of the Internet discourse: forums (N. Lukashenko), the Internet news (N. Kolomiets), blogs (T. Germasova, K. Lazutkin), Internet diaries (S. Zaborovskaya) (нема у списку літератури).

In our research, the Internet discourse is represented by texts that are found in the Internet and are the result of the thinking and speech activity of the anonymous addressee and the recipient characterized by the unity of the verbal and nonverbal component (creolized texts) and have a significant pragmatic potential that allows them to form the modern youth audience's viewpoint. We can note that these texts, in a figurative form, show patterns of behavior and relationships that are considered to be highly moral, or in the correct form provide advice, i. e. have a suggestive effect on the recipient.

Thus, in the context of our study, following E. Sheigal we define the discourse as a communication system, a field of communicative practices, studied in the real and potential (virtual) aspects, where the real aspect is marked with the current speech activity and its results - texts, the potential of which is represented by a set of icons, serving a separate communication (Sheigal, 2000). Today, the Internet accumulates various formats of communication and serves as a means of transmitting information, unlimited, neither time nor space. Due to this a new type of discourse - the Internet discourse is appeared.

The Internet, being a high-technological and at the same time highly dynamic communicative space, is in constant motion and constant evolution. According to this, there are completely new forms of Internet communication, and the old ones are modified in one way or another.

Sociologists come to the conclusion that in our time a social reality of a new type is formed, it is the media reality in which the objective reality and the picture of the world are fused together, but the personal and social life are interwoven with technical means - the Internet, advertising, cinema and television.

In the situation of computerization of modern society, the influence of the media on the way of life, the worldview and the consciousness of most people is evident.

An attempt to overcome the language barrier of representatives of various linguistic cultures is playing a dominant role of non-verbal information in today's global communication and the emergence of new visual and verbal forms of the Internet communication. Non-verbal information is more easily coded and decoded, which makes it possible to affect the conceptual picture of the world of "global and standardized" recipients.

\section{Demotivators as special forms of communication}

A demotivator (demo poster) as an object of philological research is relevant, as today the interest in the problem of polycodal or creolized texts as special forms of communication (banners, advertising, clips and demotivators) has increased. Modern people are always surrounded by different icon systems, and non-verbal means are increasingly involved in transmitting and storing information.

Demo posters appeared in the United States at the end of the $20^{\text {th }}$ century, when western business began to use manipulative technologies in human resource management. To increase productivity and employee interest, motivational posters began to be used as a kind of social advertising. Their goal was to promote a positive view on the world, an active life position and the formation of a certain mood in society, especially among young people. Because of the fact that these motivators were not interesting and not talented, the practice of their parody became widely used. In this way, the theme of demotivators has gradually expanded, and today they have been globally distributed among the Internet users in different countries (Bugayeva, 2011: 148).

According to I. Bugayeva's conception, a demotivator is a picture consisting of a graphic component in a black frame and a slogan that explains it. So demotivators have a clear composition and contain three main elements: an image, a slogan or a slogan in big letters and an explanatory part in lower case letters. In this way, the linguistic elements and visuals (photo, drawing, color, font) are perceived as a single informational whole (Bugayeva, 2011: 149).

Among the main features of demotivators the following should be singled out:

1) the direction to satisfy the cultural needs of "readers-readers";

2) clear general features, the same genre features and conventions for the creation;

3 ) ensuring the realization of the creative potential of the personality and creative perception of reality;

4) existence predominantly within the Internet space;

5) belonging to the youth style (Bugayeva, 2011: 128-129). 
According to the linguists' conception, the genre characteristics of demotivators are determined by their belonging to polymodal texts, which are characterized by intertextuality, hypertext, creolosity, as well as to the works of the speech genre, which is characterized by the anonymity of the author, the multiplicity and uncertainty of the addressee (Bugayeva, 2011: 151-152).

Demotivational posters are a special way of transmitting information, as prepositions are important for the fullest possible understanding of its meaning,: a demotivator can contain such semantic components that do not find direct expression, and the reader decodes these meanings on the basis of their own experience, knowledge of typical situations, historical and cultural background and knowledge (Bugayeva, 2011: 149).

Thus, O. Golikov and A. Kalashnikova distinguish the following types of demotivators: 1) original or classical, created according to the rules and aimed at "destroying" social values; 2) humorous or "demotivators without demotivation", the purpose of which is the comical representation of fragments of reality; 3) social and advertising which promote traditional values through a critical view of the situation; 4) self-presentational, aimed at expressing the attitude to a particular subculture; 5) esoteric, aimed at popularizing Internet memes or certain phrases; 6) philosophical ones demonstrating ideological position and worldview (Golikov, Kalashnikova, 2010: 127-128).

\section{Demotivational posters: functional and pragmatic aspects}

The main function of demotivational posters is considered to be a cognitive one, as the information presented in demotivators can influence the recipients, forming their way of thinking and their evaluative and normative system. Demotivators also carry out volitional, axiological, aesthetic, emotional and expressive functions, the essence of which lies in having certain impact on the modern person. The mixture of two planes (visual and verbal) within a single demo poster determines the appearance of a comical effect, which is impossible without comical comprehension of one or another phenomenon. Such comical comprehension allows re-evaluating the phenomenon or situation in the mind of the recipients, changing their system of values. This is one of the aims which demotivators are created for.

According to O. Golikov and A. Kalashnikova's classification of demotivational posters, we single out such types of demotivators that determine their pragmatic potential and function as well:

1. Original or classical demotivators, created according to the rules and aimed at "destroying" social values.

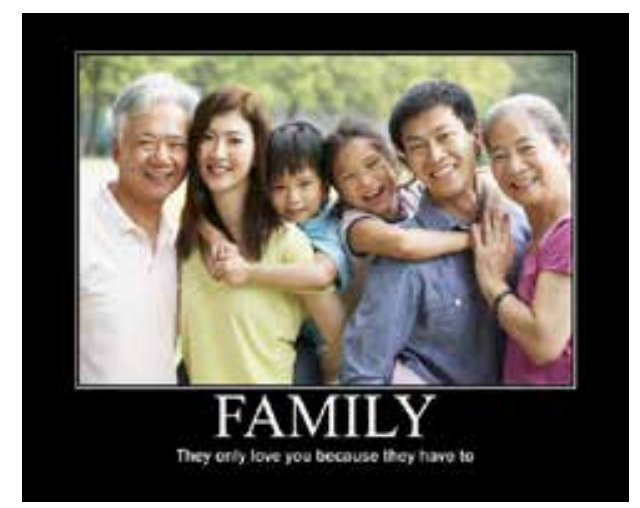

In the given demotivational poster the role of family in people's life is criticized. A visual component demonstrates happy faces of the family members that is verbally expressed in a slogan FAMILY. But the message below "They only love you because they have to" gives an opposite idea: family is just the bonds of blood that unite people without their personal desire and that can cause certain problems in unwilling communication between relatives. Such phrase only questions the significance of family in the world and "destroys" the values of family relations;

2. Humorous or "demotivators without demotivation", the purpose of which is the comical representation of fragments of reality.

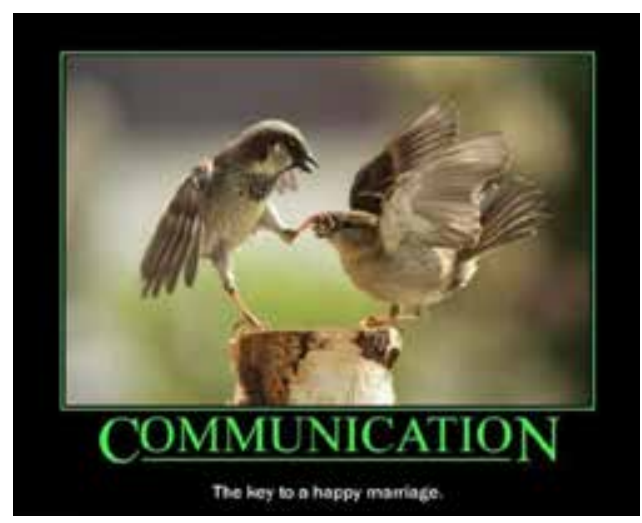


This demotivational poster is a classical example of a demotivator which has three elements: the slogan COMMUNICATION, a verbal message and a visual component, that is sufficient in comprehension of the idea of the whole poster. In a visual part of the demotivator we can see two sparrows who imitate a married couple. One of the birds shows a dominant position over the other that reflects unequal family roles which are rather typical in our society. Traditional understanding of happy marriage is based on the created rule: if one of the spouses speaks, the other keeps silence. This idea is expressed in the given verbal component: "The key to a happy marriage" and creates a humorous effect of the demotivator.

3. Social and advertising demotivators, which promote traditional values through a critical view of the situation.

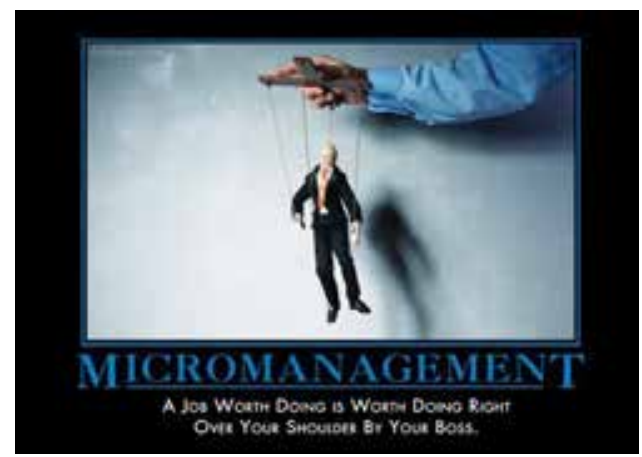

The other demotivational poster tries, in a humourous way, to prove us that

everything you want to do can be controlled and changed by your boss as he decided it. Verbal component: " $A$ job worth doing is worth doing right over your shoulders by your Boss" transmits the idea, that a human is a doll in someone's hands and his life is all the time managed by other humans and universal powers. This is realized on a visual level by the image of a puppet whose hands and legs work by the strings being pulled.

4. Self-presentational demotivators, aimed at expressing the attitude to a particular subculture.

A visual component in the following demotivator is understood only in its connection with the verbal part, as the image of a smiling girl and a burning house at the background confuses the recipient.

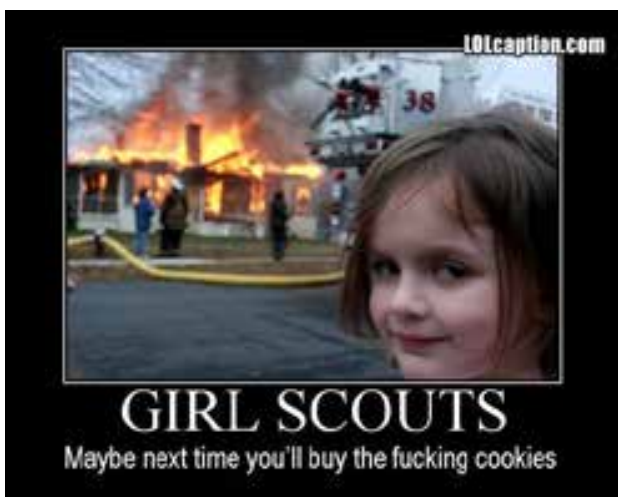

The verbal component: "May be next time you'll buy the fucking cookie" and the slogan GIRL SCOUTS give a key to solve this puzzle. The Girl Scout activity most familiar to the general public is the annual sale of Girl Scout Cookies as a money-earning opportunity for councils and troops. This poster criticizes people's unwillingness to support the tradition of buying cookies. The reaction of this girl demonstrates the real attitude of people towards the volunteer organization in a humorous way.

5. Esoteric, aimed at popularizing the Internet memes or certain phrases.

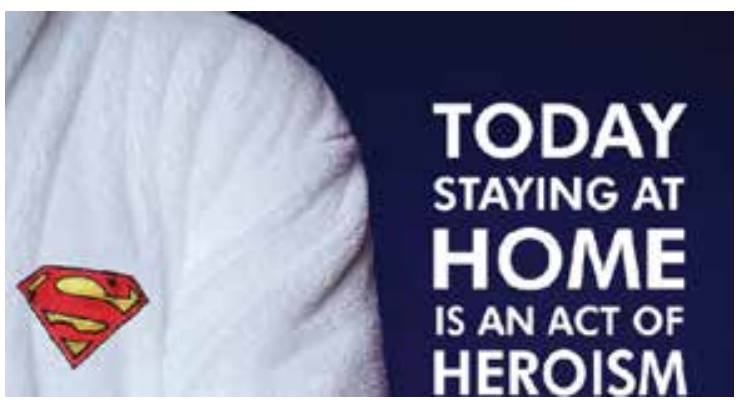


The given demotivational poster reveals today's situation in the world in the conditions of COVID-19 and lockdown. The phrase "stay at home" became the most popular motto during the last months: it appeared as a hashtag in social networks and on TV; pop-stars streamed videos calling for staying at home and encouraging people to have normal life in new circumstances. After so many months "isolation" is really percepted as a heroic act as people are deprived of the opportunity to visit their family, meet friends and have a happy free life. The verbal component "TODAY staying at HOME is an act of HEROISM" proves the idea that home has become a prison for the majority of people. Moreover, visually the depiction of a Superman label on a home robe is a humorous way to show this heroism that has nothing to do with the essence of this phenomenon, because for staying at home people do not need superpowers.

6. Philosophical demotivators, which demonstrate an ideological position and worldview.

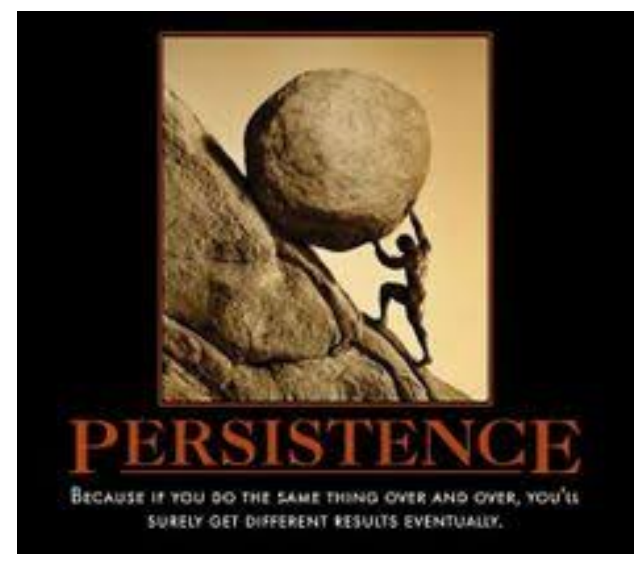

The given demotivational poster explains the notion PERSISTENCE, which is the slogan of the demotivator, and states the role of it in human labour and achievements. The verbal component: "Because if you do the same thing over and over, you'll surely get different results eventually" encourages people to achieve results though they are sometimes very insufficient. In our opinion, the demotivator shows the idea that any labour is not in vain and sometimes the process can be more important that the result. The visual element of the poster contains an allusion on the Greek myth about Sisyphus who was forced to roll an immense boulder up a hill that rolled down every time when it neared the top. The expression Sisyphus labour became idiomatic and is used to describe useless work. In this context it underlines the idea that any work is not useless and can bring results.

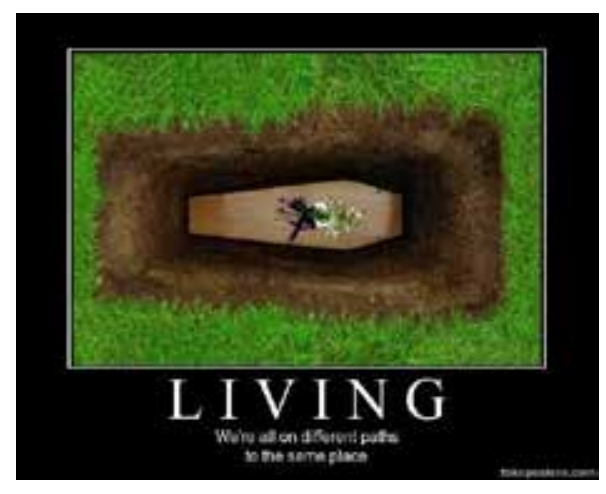

The other philosophical demotivator is dedicated to the essence of our life. The verbal component in this demotivator is represented by the phrase: "We're all on different path to the same place". The visual image - a coffin in the ground conveys the idea of death as an inevitable part of life and life that always ends up with death. The nominative unit path verbalizes the concept of the way in terms of which the concept of Life is comprehended. Thus, we reconstruct the conceptual metaphor LIFE IS A WAY. We all move in certain directions, choosing our way each day but the final destination is always the same, as nobody can avoid death.

So, the analysis of the following examples shows that the type of demotivators can determine their pragmatic potential: original, philosophical, social and advertising demotivators promote the main values and realize the volitional intention of the speaker, i.e. a suggestive impact on the recipient that helps to create a spiritual guidance and a new type of thinking among young people; humorous and esoteric demotivators depict famous facts from youth's life in an ironical and sarcastic manner, disclose social reality, have entertaining character, carrying out both emotional, expressive functions and a function of forming virtual reality. 


\section{Conclusions}

A demotivational poster is a special way of transmitting information in the Internet that has a clear composition and consists of three elements that are percepted as an informational whole: an image (visual component), a slogan and an explanatory part. A demotivator as a product of the postmodern worldview enters our lives, defining its moral and value orientations, the attitude towards the surrounding world. Demotivators are created as a series on one theme, they are grouped into specific blocks according to a common theme, idea and ideology. Modern demotivators provide the realization of creative potential of an individual and formation of evaluative and normative systems of young people. During the investigation various types of demotivational posters were analyzed that demonstrated their different functional and pragmatic potential depending on their verbal content.

\section{Bibliography:}

1. Бацевич Ф.С. Основи комунікативної лінгвістики. Підручник. Київ : Академія, 2004. 344 с.

2. Бугаева И.В. Демотиваторы как новый жанр в Интернет-коммуникации жанровые признаки, функции, структура, стилистика. 2011. URL: http://www.rastko.rs/filologija/stil/2011/10Bugaeva.pdf (date of access: 10.08.2020).

3. Виноградова Т.Ю. Русская и сопоставительная филология: лингвокульторологический аспект. Казань, 2004. C. 63-67.

4. Галичкина Е.Н. Специфика компьютерного дискурса на английском и русских языках (на материале жанра компьютерных конференций) : дис. ... канд. филол. наук : 10.02 .20 «Сравнительно-историческое, типологическое и сопоставительное языкознание». Астрахань, 2001.212 с.

5. Голиков А.С., Калашникова А.А. Демотиваторы в Интернет-коммуникации: генезис, смысл, типология. Вестник Харьковского государственного университета. 2010. Вып. 16. С. 124-130.

6. Загнітко А.П. Лінгвістика тексту: Теорія і практикум. Науково-навчальний посібник. Вид. 2-ге, доповнене і перероблене. Донецьк : ТОВ «Юго-Восток Лтд», 2007. 313 с.

7. Карасик В.И. О типах дискурса. Языковая личность: институциональный и персональный дискурс: сб. науч. тр. Волгоград : Перемена, 2000. С. 5-20.

8. Лутовинова О.В. Демотиватор как вид сетевого творчества. Вестник Волгоградского государственного университета. Серия 2. Языкознание. 2016. Т. 15. № 3. С. 28-36. DOI: https://doi.org/10.15688/jvolsu2.2016.3.3 (date of access: 10.08 .2020$)$.

9. Макарук Л.Л. Проблеми дослідження семіотично ускладнених текстів. Науковий вісник Чернівещького університету: збірник наукових пращь. 2014. С. 69-72.

10. Шевченко І.С. Проблеми типології дискурсу. Дискурс як когнітивно-комунікативний феномен : кол. монографія / під заг. ред. Шевченко І.С. Харків : Константа, 2005. С. 233-237.

11. Шейгал Е.И. Семиотическое пространство политического дискурса : дис. ... докт. филол. наук : 10.02.19 / Волгоградский государственный университет. Волгоград, 2000. 440 с.

12. Bateman J. A multimodal discourse theory of visual narrative. Journal of Pragmatics. 2014. № 74. P. 180-208.

13. Cambridge Dictionary. URL: https://dictionary.cambridge.org (date of access: 10.08.2020).

14. Crystal D. Language and the Internet. Cambridge : Cambridge University Press, 2004. 272 p.

15. Crystal D. Text and discourse. The Cambridge Encyclopedia of Language. Second edition. Cambridge : Cambridge University Press, 1997. P. 116-117.

16. Herring S.S. Computer-Mediated Discourse. URL: http://www.let.rug.nl/redeker/herring.pdf(date of access: 10.08.2020).

17. Kress G.R. Multimodal Discourse: the modes and the media of contemporary communication. London : Edward Arnold, 2002. $152 \mathrm{p}$.

18. Liebert W. Multimodal Text. The Encyclopedia of Applied Linguistics. Oxford: Blackwell Publishing, 2013. P. 4338-4336.

19. Veb-account "Facebook". URL: https://uk-ua.facebook.com/ (date of access: 10.08.2020).

20. Veb-account "Instagram". URL: https://www.instagram.com/?hl=ru (date of access: 10.08.2020).

\section{References:}

1. Batsevych, F.S. (2004) Osnovy kommunikativnoi linhvistyky: Pidruchnyk. [The basis of communicative linguistics: Textbook]. Kyiv: Akademiya. 344 p. [in Ukrainian].

2. Bugayeva, I.V. (2011) Demotivatory kak novuy zhanr v Internet kommunikatsii: zhanrovyye priznaki, funktsii, struktura, stilistika [Demotivators as a new genre in Internet communication: genre's characteristics, functions, structure and stylistcs] URL: http://www.rastko.rs/filologija/stil/2011/10Bugaeva.pdf [in Russian].

3. Vinoghadova, T.Ju. (2004) Russkaya i sopostavitelnaya filologiya: lingvokulturologicheskiy aspect [Russian and comparative philology: linguocultural aspect]. Kazan. P. 63-67 [in Russian].

4. Galichkina, E.N. (2001) Spetsifika kompyuternogo diskursa na angliyskom i russkom yazykakh (na materiale zhanra komputernykh konferentsiy) [Specificity of computer discourse in the English and Russian languages (case study genre of computer conferences)]: Diss. Cand. Of Phil. Sciences: 10.02.20. Astrahan State University. 212 p. [in Russian]

5. Golikov, A.S. Kalashnikova, A.A. (2010) Demotivatory v Internet-kommunikatsii: genezis, smysl, tipologiya [Demotivators in Internet-communication: genesis, sense, typology] Vestnik Kharkovskoho gosudarstvennogo universiteta [Bulletin of Kharkov State university]. Vol. 16. P. 124-130 [in Russian].

6. Zahnitko, A.P. (2007) Linhvistika tekstu: Teoriia i praktykum [Text linguistics: Theory and practice]. Naukovonavchalnyi posibnyk. Vud. 2-e dopovnene i pereroblene. Donetsk: TOV "Yuho-Vostok LTD". 313 p. [in Ukrainian]. 
7. Karasik, V.I. (2000) O tipakh diskursa [About discourse typology] Yazykovaya lichnost: institutsionalnyy i personalnyy diskurs: [Language personality: institutional and personal discourse]. Collection of scientific works. Volgograd: Peremena, P. 5-20 [in Russian].

8. Lutovinova, O.V. (2016) Demotivator kak vid setevogo tvorchestva [Demotivator as a kind of net art] Vestnik Volgohradskogo gosudarstvennogo universiteta. Seriy 2 "Lingvistika" [Bulletin of Volgograd State University. Series "Linguistics”] V. 15. No 3. P. 28-36. DOI: https://doi.org/10.15688/jvolsu2.2016.3.3. [in Russian].

9. Makarchuk, L.L. (2014) Problemy doslidzhennia semiotychno uskladnenykh tekstiv [Problems of researching semiotically complicated texts] Naukovyi visnyk Chernivetskoho u-tu: zbirnyk naukovykh prats. [Scientific bulletin of Chernivtsy University: collection of scientific works]. Chernivtsi : Publishing and printing center "Rodovid", P. 69-72 [in Ukrainian].

10. Shevchenko, I.S. (2005) Problemy tipolohii dyskursu: Dyskurs yak kohnityvno-komunikatuvnyi fenomen [Problems of discourse typology. Discourse as a cognitive and communicative phenomenon]. Kharkiv: Konstanta. P. $233-237$ [in Ukrainian].

11. Sheigal, E.I. (2000) Semioticheskoye prostranstvo politicheskogo diskursa [Semiotic space of political discourse]: Diss. Doctor Of Phil. Sciences: 10.02.19. Volgograd State University. Volgograd. 440 p. [in Russian].

12. Bateman, J. (2014) A multimodal discourse theory of visual narrative. Journal of Pragmatics. № 74. P. 180-208 [in English].

13. Cambridge Dictionary. URL: https://dictionary.cambridge.org [in English].

14. Crystal, D. (2004) Language and the Internet. Cambridge: Cambridge University Press, 272 p. [in English].

15. Crystal, D. (1997) Text and discourse. The Cambridge Encyclopedia of Language. Second edition. Cambridge: Cambridge University Press, P. 116-117 [in English].

16. Herring, S.S. (2014) Computer-Mediated Discourse. URL: http://www.let.rug.nl/redeker/herring.pdf [in English].

17. Kress, G.R. (2002) Multimodal Discourse: the modes and the media of contemporary communication. London: Edward Arnold, 152 p. [in English].

18. Liebert, W. (2013) Multimodal Text. The Encyclopedia of Applied Linguistics. Oxford: Blackwell Publishing. P. 4338-4336 [in English].

19. Veb-account "Facebook". URL: https://uk-ua.facebook.com/ [in English].

20. Veb-account "Instagram". URL: https://www.instagram.com/?hl=ru [in English].

Стаття надійшла до редакиії 28.08.2020

The article was received 28 August 2020 